\title{
Control of Excitation/Inhibition Balance in a Hippocampal Circuit by Calcium Sensor Protein Regulation of Presynaptic Calcium Channels
}

\author{
Evanthia Nanou, ${ }^{1}$ Amy Lee, ${ }^{2}$ and William A. Catterall ${ }^{1}$ \\ ${ }^{1}$ Department of Pharmacology, University of Washington, Seattle, Washington 98195 and ${ }^{2}$ Department of Molecular Physiology and Biophysics, University \\ of Iowa, Iowa City, Iowa 52242
}

Activity-dependent regulation controls the balance of synaptic excitation to inhibition in neural circuits, and disruption of this regulation impairs learning and memory and causes many neurological disorders. The molecular mechanisms underlying short-term synaptic plasticity are incompletely understood, and their role in inhibitory synapses remains uncertain. Here we show that regulation of voltagegated calcium $\left(\mathrm{Ca}^{2+}\right)$ channel type $2.1\left(\mathrm{Ca}_{\mathrm{V}} 2.1\right)$ by neuronal $\mathrm{Ca}^{2+}$ sensor $(\mathrm{CaS})$ proteins controls synaptic plasticity and excitation/ inhibition balance in a hippocampal circuit. Prevention of $\mathrm{CaS}$ protein regulation by introducing the IM-AA mutation in $\mathrm{Ca}_{\mathrm{V}} 2.1$ channels in male and female mice impairs short-term synaptic facilitation at excitatory synapses of CA3 pyramidal neurons onto parvalbumin (PV)-expressing basket cells. In sharp contrast, the IM-AA mutation abolishes rapid synaptic depression in the inhibitory synapses of PV basket cells onto CA1 pyramidal neurons. These results show that CaS protein regulation of facilitation and inactivation of $\mathrm{Ca}_{\mathrm{V}} 2.1$ channels controls the direction of short-term plasticity at these two synapses. Deletion of the CaS protein CaBP1/caldendrin also blocks rapid depression at PV-CA1 synapses, implicating its upregulation of inactivation of $\mathrm{Ca}_{\mathrm{V}} 2.1$ channels in control of short-term synaptic plasticity at this inhibitory synapse. Studies of local-circuit function revealed reduced inhibition of CA1 pyramidal neurons by the disynaptic pathway from CA3 pyramidal cells via PV basket cells and greatly increased excitation/inhibition ratio of the direct excitatory input versus indirect inhibitory input from CA3 pyramidal neurons to CA1 pyramidal neurons. This striking defect in local-circuit function may contribute to the dramatic impairment of spatial learning and memory in IM-AA mice.

Key words: calcium channels; calcium sensor proteins; calmodulin; excitation/inhibitions; neuro circuit; synaptic plasticity

Significance Statement

Many forms of short-term synaptic plasticity in neuronal circuits rely on regulation of presynaptic voltage-gated $\mathrm{Ca}^{2+}\left(\mathrm{Ca}_{\mathrm{V}}\right)$ channels. Regulation of $\mathrm{Ca}_{\mathrm{v}} 2.1$ channels by neuronal calcium sensor $(\mathrm{CaS})$ proteins controls short-term synaptic plasticity. Here we demonstrate a direct link between regulation of $\mathrm{Ca}_{\mathrm{v}} 2.1$ channels and short-term synaptic plasticity in native hippocampal excitatory and inhibitory synapses. We also identify $\mathrm{CaBP} 1 /$ caldendrin as the calcium sensor interacting with $\mathrm{Ca}_{\mathrm{v}} 2.1$ channels to mediate rapid synaptic depression in the inhibitory hippocampal synapses of parvalbumin-expressing basket cells to CA1 pyramidal cells. Disruption of this regulation causes altered short-term plasticity and impaired balance of hippocampal excitatory to inhibitory circuits.

\section{Introduction}

Synapses use short-term synaptic plasticity to encode, fine-tune, and transfer information (Zucker and Regehr, 2002; Abbott and

Received Jan. 4, 2018; revised March 15, 2018; accepted April 1, 2018.

Author contributions: E.N. and W.C. wrote the first draft of the paper; E.N., A.L., and W.C. edited the paper; E.N., A.L., and W.C. designed research; E.N. performed research; A.L. and W.C. contributed unpublished reagents/analytic tools; E.N. and A.L. analyzed data; E.N. and W.C. wrote the paper.

This work was supported by U.S. National Institutes of Health Research Grant R01 NSO22625 to W.A.C., and NIH Research Grant R01 NS084190 and a Carver Research Program of Excellence Award to A.L.

The authors declare no competing financial interests.

Correspondence should be addressed to Dr. William A. Catterall, Department of Pharmacology, University of Washington, Seattle, WA 98195. E-mail: wcatt@uw.edu.
Regehr, 2004). Synaptic facilitation increases EPSCs and IPSCs in response to repetitive stimuli, whereas rapid synaptic depression reduces EPSCs and IPSCs in trains of impulses (Zucker and Regehr, 2002; Abbott and Regehr, 2004). Short-term facilitation is important in modulating information-processing in the hippocampal circuit (Buzsaki and Moser, 2013; Bartley and Dobrunz, 2015); however, the role of rapid synaptic depression in circuit function is poorly understood (Anwar et al., 2017). Recent studies advanced knowledge of molecular mechanisms required for short-term synaptic facilitation in excitatory synapses (Cat- 
terall and Few, 2008; Catterall et al., 2013; Jackman and Regehr, 2017), but mechanisms underlying short-term synaptic facilitation in inhibitory synapses and mechanisms that induce rapid depression on the ms timescale are largely unknown. We use a mouse genetic model with impaired regulation of presynaptic calcium channels to probe these fundamental questions concerning short-term synaptic plasticity in excitatory versus inhibitory synapses and control of excitation/inhibition balance in neural circuits.

Voltage-gated calcium $\left(\mathrm{Ca}^{2+}\right)$ channel type $2.1\left(\mathrm{Ca}_{\mathrm{V}} 2.1\right)$ conducts P/Q-type $\mathrm{Ca}^{2+}$ currents that initiate synaptic transmission at excitatory and inhibitory synapses (Mori et al., 1991; Starr et al., 1991; Dunlap et al., 1995; Tsien et al., 1995; Westenbroek et al., 1995; Catterall, 2011; Zamponi et al., 2015). Repetitive stimulation of $\mathrm{Ca}_{\mathrm{V}} 2.1$ channels causes $\mathrm{Ca}^{2+}$-dependent facilitation followed by $\mathrm{Ca}^{2+}$-dependent inactivation, which is mediated by sequential binding of $\mathrm{Ca}^{2+}$ to calmodulin bound to a bipartite regulatory site in the C-terminal domain (Lee et al., 1999, 2000, 2003; DeMaria et al., 2001). This regulatory site can also be occupied by the family of neuronal calmodulin-like CaS proteins (Haeseleer and Palczewski, 2002), which displace calmodulin and enhance facilitation or inactivation (Lee et al., 2002; Tsujimoto et al., 2002; Lautermilch et al., 2005; Yan et al., 2014).

$\mathrm{Ca}_{\mathrm{V}} 2.1$ channels are required for synaptic facilitation in the Calyx of Held (Inchauspe et al., 2004), and timing of their facilitation and inactivation correlates with synaptic facilitation and the rapid phase of synaptic depression (Borst and Sakmann, 1998; Cuttle et al., 1998; Forsythe et al., 1998; Xu and Wu, 2005). Exogenous expression of $\mathrm{Ca}_{\mathrm{V}} 2.1$ channels in cultured superior cervical ganglion neurons induces synaptic facilitation, which is blocked by a mutation (IM-AA) that prevents facilitation of $\mathrm{Ca}_{\mathrm{V}} 2.1$ by calmodulin (Mochida et al., 2008). Expression of $\mathrm{CaS}$ proteins in these neurons overrides regulation by calmodulin and favors either facilitation or depression (Leal et al., 2012; Yan et al., 2014). These results led to the hypothesis that the direction and extent of short-term synaptic plasticity may be controlled by differential regulation of $\mathrm{Ca}_{\mathrm{V}} 2.1$ channels by $\mathrm{CaS}$ proteins in vivo (Catterall and Few, 2008; Catterall et al., 2013).

Mice harboring the IM-AA mutation in their $\mathrm{Ca}_{\mathrm{V}} 2.1$ channels do indeed have impaired short-term synaptic plasticity at excitatory synapses in hippocampus and neuromuscular junction (Nanou et al., 2016a,b). The input/output functions of synaptic circuits in brain depend crucially on balance of excitatory to inhibitory neurotransmission, the E/I ratio. Here we show that short-term synaptic plasticity is controlled by CaS protein regulation of $\mathrm{Ca}_{\mathrm{V}} 2.1$ channels in both excitatory and inhibitory synapses in the hippocampus. At the key inhibitory synapse of PV basket cells onto CA1 pyramidal neurons, rapid synaptic depression is blocked in IM-AA mice, leading to dramatic change in E/I ratio in this local hippocampal circuit. Genetic deletion of the $\mathrm{CaS}$ protein $\mathrm{CaBP} 1 /$ caldendrin, which blocks facilitation and enhances inactivation of $\mathrm{Ca}_{\mathrm{V}} 2.1$ channels, prevents rapid depression of synapses of PV basket cells onto CA1 pyramidal neurons. These results indicate that enhanced inactivation of $\mathrm{Ca}_{\mathrm{V}} 2.1$ channels by $\mathrm{CaBP} 1 /$ caldendrin causes rapid depression at this synapse. Our results demonstrate an unexpected role for regulation of $\mathrm{Ca}_{\mathrm{V}} 2.1$ channels by $\mathrm{CaS}$ proteins in controlling rapid synaptic depression in a key inhibitory synapse and in sustaining balanced circuit function in the hippocampus.

\section{Materials and Methods}

Animals. All experiments were performed with procedures approved by the Institutional Animal Care and Use Committee of the University of Washington. IM-AA mice with a point mutation in the IQ-like motif of
$\mathrm{Ca}_{\mathrm{V}} 2.1$ (IM $\gg \mathrm{AA}$; ATCATG to GCCGCT) were generated by Ingenious Targeting Laboratory. The mutation (within exon 40) was generated by PCR mutagenesis and confirmed by sequencing. Traditional blastocyst injection of ES cells expressing the targeting vector resulted in chimeric mice. These chimeric mice were mated first to generate heterozygotes, which were then backcrossed for 10 generations with C57BL/6J mice (RRID:IMSR_JAX:000664) to generate homozygous IM-AA mutant mice in a pure genetic background. To target PV interneurons for whole-cell recordings we crossed a PV-Cre mouse line (The Jackson Laboratory, stock 008069; RRID:IMSR_JAX:008069) with a reporter line with red fluorescent protein Td-tomato (The Jackson Laboratory, stock 007905; RRID:IMSR_JAX:007905) in PV cells to produce PV-Tom mice. PVTom mice were then crossed with the IM-AA mouse line to create homozygous IM-AA/PV-Tom mice. For optogenetic experiments, we crossed the PV-Cre line with mice expressing channelrhodopsin (ChR2; The Jackson Laboratory, stock 012569) to generate PV-ChR2 mice. Then the PVChR2 mice were crossed with the IM-AA mice to generate homozygous IM-AA/PV-ChR2 mice. The CaBP1/caldendrin knock-out mice were developed at the University of Iowa (Kim et al., 2014).

Electrophysiology in hippocampal slices. Wild-type (WT) and IM-AA mice 16- to 24-d-old were anesthetized with isoflurane. Brains were rapidly removed and placed in ice-cold, high-sucrose cutting solution containing the following (in mM): 75 sucrose, $25 \mathrm{NaHCO}_{3}, 25$ glucose, 2.5 $\mathrm{KCl}, 1.25 \mathrm{NaH}_{2} \mathrm{PO}_{4}, 87 \mathrm{NaCl}, 7 \mathrm{MgCl}_{2}$, and $0.5 \mathrm{CaCl}_{2}$. Acute transverse hippocampal slices $(400 \mu \mathrm{m})$ were cut on a 1000 Plus Vibratome in the high-sucrose cutting solution and transferred immediately to an incubation chamber containing artificial CSF composed of the following (in mM): $125 \mathrm{NaCl}, 3 \mathrm{KCl}, 2 \mathrm{CaCl}_{2}, 2 \mathrm{MgCl}_{2}, 1.25 \mathrm{NaH}_{2} \mathrm{PO}_{4}, 26 \mathrm{NaHCO}_{3}$, and 10 glucose, saturated with $95 \% \mathrm{O}_{2}$ and $5 \% \mathrm{CO}_{2}$. The slices were allowed to recover at $37^{\circ} \mathrm{C}$ for $45 \mathrm{~min}$ and then were maintained at room temperature for at least $30 \mathrm{~min}$ before recording.

Slices were transferred to a submerged recording chamber mounted on a Nikon microscope (E600FN) or an Olympus BX51 microscope equipped with a Hamamatsu Orca-03G CCD camera equipped for infrared differential interference contrast microscopy and were perfused with ACSF at a rate of $1.5 \mathrm{ml} / \mathrm{min}$ at room temperature. All experiments were performed in the presence of the $\mathrm{Ca}_{\mathrm{V}} 2.2$ blocker $\omega$-Conotoxin GVIA $(1 \mu \mathrm{M})$. EPSCs were induced by stimulating Schaffer collaterals $(0.3 \mathrm{~ms})$ in stratum radiatum by a concentric bipolar stimulating electrode (FHC). EPSCs were recorded either from CA1 pyramidal cells which were visualized by infrared differential interference contrast or from fluorescently identified PV-positive interneurons using a Nikon Intensilight C-HGFI. Cells were held at $-60 \mathrm{mV}$ to record AMPA-mediated EPSCs in the presence of the NMDA blocker AP-V $(50-100 \mu \mathrm{M})$, the $\mathrm{GABA}_{\mathrm{A}}$ blocker picrotoxin $(50 \mu \mathrm{M})$ and the $\mathrm{GABA}_{\mathrm{B}}$ blocker CGP55845 hydrochloride $(10 \mu \mathrm{M})$. Evoked IPSCs were recorded at $0 \mathrm{mV}$ in the presence of the AMPA receptor blocker CNQX $(20 \mu \mathrm{M})$ and the NMDA blocker AP-V $(100 \mu \mathrm{M})$. Electrically evoked IPSCs were induced as for EPSCs. Optically evoked IPSCs were induced by activating PV/Channelrhodopsin interneurons optically using a coolLED pE-100. Laser light illumination $(0.5 \mathrm{~ms})$ was given using a water-immersed $60 \times$ objective to produce a maximum $80-\mu \mathrm{m}$-diameter spot. Miniature IPSCs were recorded at $0 \mathrm{mV}$ in the presence of $1 \mu \mathrm{M}$ TTX. The detection threshold for miniature IPSCs was set at $8 \mathrm{pA}$. The averaged miniature IPSC amplitude, frequency, rise time and decay time for each cell was calculated during the initial $4 \mathrm{~min}$ period after whole-cell access was obtained. Whole-cell recording pipettes $(4-6 \mathrm{M} \Omega$ ) were filled with a solution containing the following (in $\mathrm{mM}$ ): 145 Cs-gluconate, $2 \mathrm{MgCl}_{2}, 10 \mathrm{HEPES}, 0.5$ EGTA, 2 Tris-ATP, $0.2 \mathrm{Na}_{2} \mathrm{GTP}$, and 5 QX-314. Data were collected with a MultiClamp 700A amplifier (Molecular Devices) or a HEKA dual EPC-10 amplifier, filtered at $2 \mathrm{kHz}$ and digitized at $10 \mathrm{kHz}$. Multiple step depolarizations were given at the beginning of every experiment to induce block of $\mathrm{Na}^{+}$and $\mathrm{Ca}^{2+}$ currents in the CA1 pyramidal cells by QX-314. Paired-pulse ratios (PPRs) were recorded using intervals of 20, 50, 80, 100, 150, and 200 ms. Evoked AMPA-mediated EPSCs and GABAmediated IPSCs were also recorded in response to trains at different frequencies $(5,10,20,50 \mathrm{~Hz})$. The ratio of excitation to inhibition was calculated by recording paired compound PSCs at $-40 \mathrm{mV}$ which contains both excitatory and inhibitory components in the presence of $100 \mu \mathrm{M}$ APV. 
A

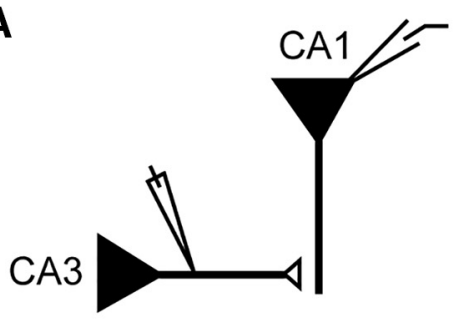

C

CA1

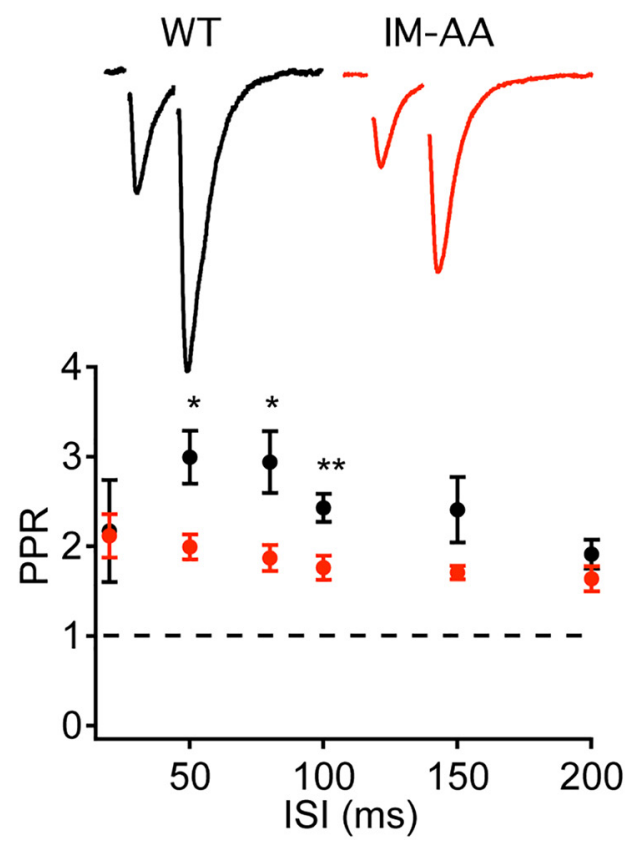

B

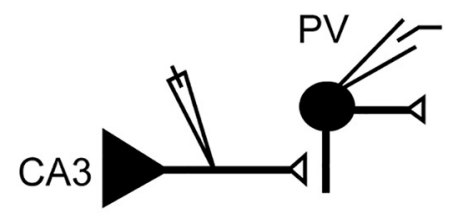

D

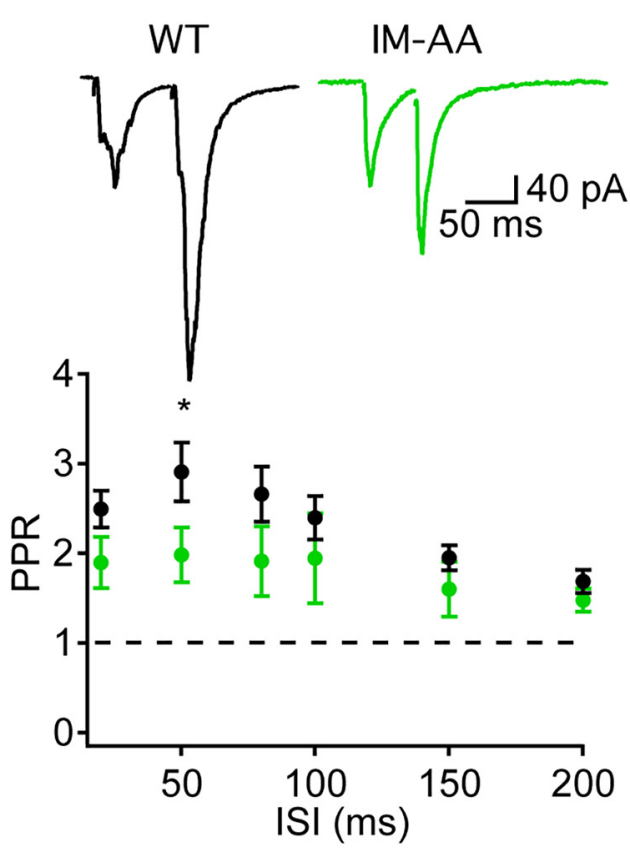

Figure 1. IM-AA mutation reduces paired-pulse facilitation in synapses of CA3 neurons onto excitatory CA1 neurons and inhibitory PV basket cells. Schematics of recording excitation from (A) CA1 pyramidal neurons and (B) PV interneurons. C, Example evoked EPSCs from WT (black) and IM-AA (red) CA1 pyramidal neurons in response to paired-pulse stimulation of SC fibers. Stimulus artifacts were blanked for clarity. PPR plotted as a function of ISI from WT (black; $n=10$ cells) and IM-AA (red; $n=10$ cells) CA1 pyramidal neurons. $p=0.02, I S I=50 \mathrm{~ms} ; p=0.03, I S I=80 \mathrm{~ms} ; p=0.007$, $|S|=100 \mathrm{~ms}$. D, Example evoked EPSCs from WT (black) and IM-AA (green) PV interneurons in response to paired-pulse stimulation of SC fibers. Stimulus artifacts were blanked for clarity. PPR plotted as a function of ISI from WT (black, $n=10$ cells) and IM-AA (green, $n=10$ cells) PV interneurons. $p=0.04, I S I=50$ ms. Recordings were made in the presence of $1 \mu \mathrm{m} \omega$-Ctx, $50 \mu \mathrm{m}$ APV, $50 \mu \mathrm{m}$ picrotoxin, and $10 \mu \mathrm{M}$ CGP55845 hydrochloride. Results for CA1-CA3 synapses were pooled from previous (Nanou et al., 2016a) and current studies, as they were not significantly different. ${ }^{*} p<0.05 .{ }^{* *} p<0.01$.

Experimental design and statistical analysis. For all experiments, at least three animals of each genotype were used (WT, IM-AA, WT/ PV-Tom, IM-AA/ PV-Tom, WT/ PV-ChR2, IM-AA/ PV-ChR2, CaBP1/caldendrin $\mathrm{KO}$; all mixed sex). The number of cells studied in each experiment is indicated in the figure legends. Data were analyzed using Clampfit (Molecular Devices; RRID:SCR_011323) and Igor Pro (Wavemetrics; RRID: SCR_000325) software. Statistical analysis was performed with GraphPad Prism (RRID:SCR_002798). Three tests confirmed that our data follow a Gaussian distribution: D’Agostino-Pearson omnibus normality test, Shapiro-Wilk normality test, and Kolmorogov-Smirnov test. Data from individual cells are presented as examples, and pooled results are presented as mean \pm SEM. Statistical significance was calculated using Student's $t$ test, except for experiments with trains of stimulation, in which two-way ANOVA was used. Differences were considered significant at $p \leq 0.05$. Exact $p$ values are given in figure legends.

\section{Results}

Short-term synaptic plasticity at excitatory synapses on excitatory versus inhibitory neurons

In some neurons, the form of short-term synaptic plasticity at their presynaptic terminals differs depending on the postsynaptic target, suggesting target-dependent control of presynaptic function (Koester and Johnston, 2005; Patel et al., 2013). In the hip- pocampus, Schaffer collaterals (SCs) of CA3 pyramidal neurons form excitatory synapses on CA1 pyramidal neurons and PVexpressing interneurons (Bartley and Dobrunz, 2015). We have recently shown that regulation of $\mathrm{Ca}_{\mathrm{V}} 2.1$ channels by $\mathrm{CaS}$ proteins is an important molecular mechanism contributing to synaptic facilitation and rapid synaptic depression in the excitatory synapses formed by SC on CA1 neurons (Nanou et al., 2016a). To determine whether synaptic facilitation and synaptic depression are also mediated by $\mathrm{CaS}$ proteins and $\mathrm{Ca}_{\mathrm{V}} 2.1$ channels in the SC synapses on inhibitory neurons, we compared synaptic plasticity in excitatory synapses of CA3 neurons that share the same presynaptic SC fibers but form synapses on excitatory CA1 pyramidal neurons (Fig. $1 A$ ) or on inhibitory PV-expressing basket cells (Fig. 1B). EPSCs were evoked by pairs of depolarizing stimuli at different interstimulus intervals (ISIs). We found that short-term synaptic facilitation in paired pulses was indistinguishable in WT SC-CA1 and SC-PV synapses (Fig. $1 C, D$, black). In both synapse types, maximal PPRs of $\sim 3$ were observed for $50 \mathrm{~ms}$ ISIs, and they declined steadily with longer ISIs (Fig. $1 C, D$, black). We next examined the effects of prevention of $\mathrm{CaS}$ binding on $\mathrm{Ca}_{\mathrm{V}} 2.1$ channels by introducing the IM-AA mutation in these channels. In synapses from IM-AA mice, we found 

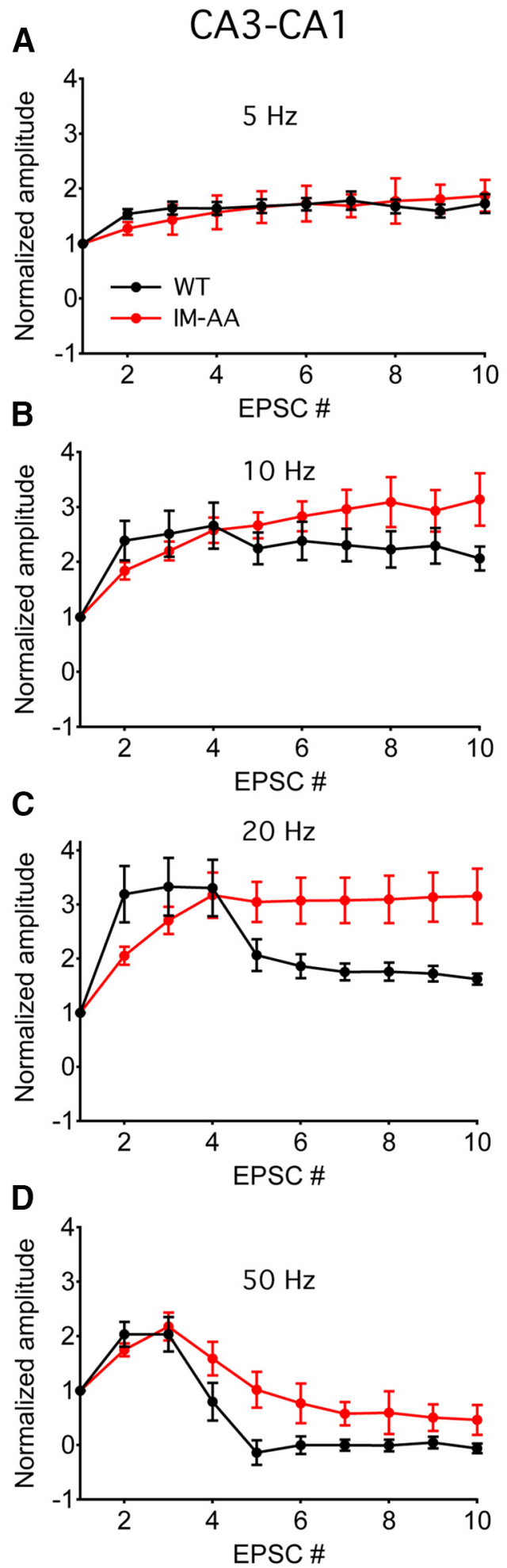

CA3-PV
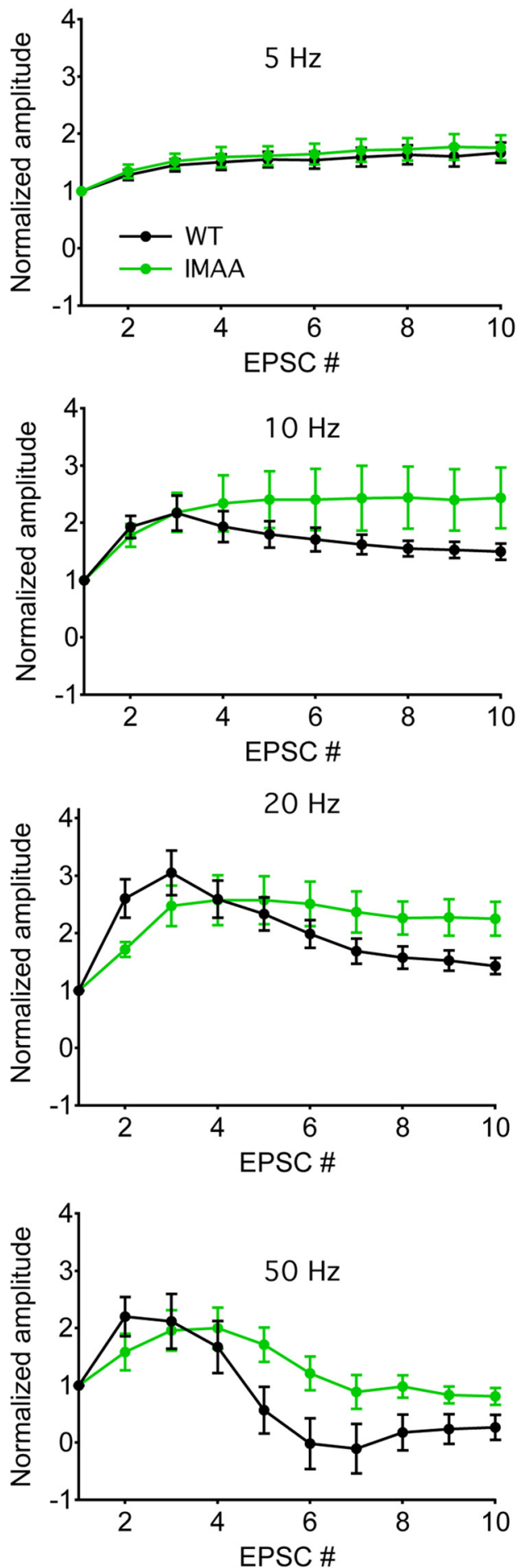

Figure 2. IM-AA mutation shifts the timing of facilitation and depression during high-frequency trains in SC-PV synapses similarly to SC-CA1 synapses. A-D, Average normalized peak amplitude of evoked EPSCs during trains from WT CA1 pyramidal (black) neurons, IM-AA CA1 pyramidal (red) neurons, WT PV (black) neurons, and IM-AA PV (green) neurons. $A, 5$ Hz: WT CA1, $n=12 ;$ WT PV,

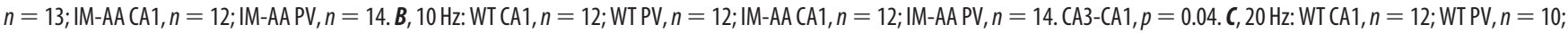
IM-AA CA1, $n=12 ;$ IM-AA PV, $n=12$. CA3-CA1, $p=0.02 ;$ CA3-PV, $p=0.02$. D, $50 \mathrm{~Hz}:$ WT CA1, $n=12 ;$ WT PV, $n=13 ;$ IM-AA CA1, $n=12 ;$ IM-AA PV, $n=10$. CA3-CA1, $p=0.0001 ;$ CA3-PV, $p=0.02$. All recordings were made in the presence of $1 \mu \mathrm{m} \omega$-Ctx, $50 \mu \mathrm{m} \mathrm{APV}, 50 \mu \mathrm{m}$ picrotoxin, and $10 \mu \mathrm{m}$ CGP55845 hydrochloride.

reduced synaptic facilitation that was similar in SC-CA1 (Fig. 1C, red) and SC-PV (Fig. 1D, green) synapses. In both cases, the maximum PPRs were reduced to $\sim 2$ in IM-AA synapses, and the dependence of facilitation on ISI was much reduced. These results indicate that $\sim 50 \%$ of paired-pulse facilitation at this synapse is caused by $\mathrm{CaS}$ protein regulation of $\mathrm{Ca}_{\mathrm{v}} 2.1$ channels. This form of synaptic facilitation is distinctive, as it is strongly dependent on ISI and peaks at ISI $=50 \mathrm{~ms}$ (Fig. $1 C, D)$. 
A

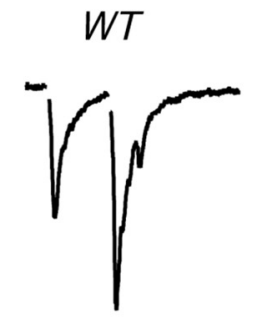

EGTA-AM

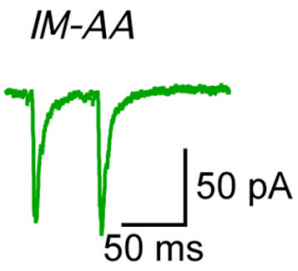

B

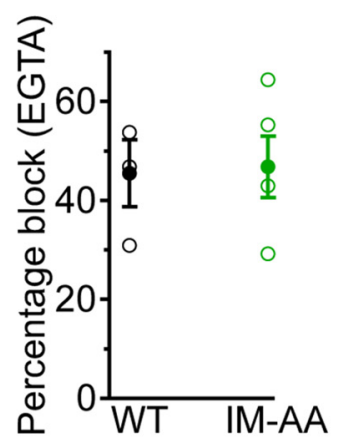

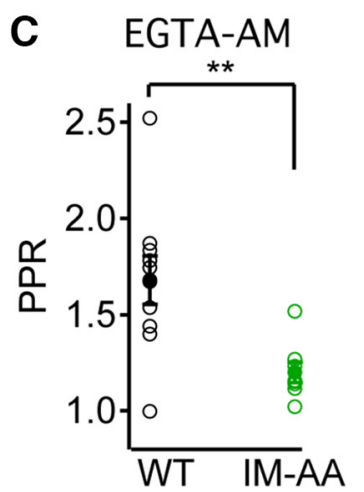

Figure 3. IM-AA mutation abolishes synaptic facilitation mediated by local calcium transients. $A$, Example evoked EPSCs from WT (black) and IM-AA (red) PV neurons in response to paired-pulse stimulation of SC fibers in the presence of $100 \mu \mathrm{m}$ EGTA-AM at $50 \mathrm{~ms}$ ISI. Stimulus artifacts were blanked for clarity. $\boldsymbol{B}$, Percentage block of evoked synaptic responses by application of $100 \mu \mathrm{M}$ EGTA-AM from WT (black; $n=3$ cells) and IM-AA (green; $n=4$ cells). $p=0.72$. C, PPR from WT (black; $n=10$ cells) and IM-AA (green; $n=8$ cells) PV neurons in the presence of $100 \mu m$ EGTA-AM. ${ }^{* *} p=0.006$. All recordings were made in the presence of $1 \mu \mathrm{m} \omega$-Ctx, $50 \mu \mathrm{m}$ APV, $50 \mu \mathrm{m}$ picrotoxin, and $10 \mu \mathrm{m}$ CGP55845 hydrochloride.

We also assessed the effect of the IM-AA mutation during more physiological stimulation by trains of action potentials at increasing frequencies (Fig. 2). Stimulus frequencies of $5 \mathrm{~Hz}$ did not cause substantial facilitation or depression. At stimulus frequencies of $10 \mathrm{~Hz}$ and $20 \mathrm{~Hz}$ in WT SC-CA1 and WT SC-PV synapses, synaptic facilitation increased and decayed to a similar degree (Fig. $2 A-C$, black). In contrast, facilitation in IM-AA SCCA1 synapses (Fig. $2 A-C$, red) and IM-AA SC-PV synapses (Fig. $2 A-C$, green) developed more slowly and decayed more slowly ( $p=0.02-0.04$; Fig. 2). At the highest frequency tested $(50 \mathrm{~Hz})$, facilitation in WT synapses decayed prominently as rapid depression developed (Fig. 2D, black), while in IM-AA synapses facilitation developed more slowly and the onset of rapid depression occurred later (Fig. 2D, red, green; $p=0.02$ ). Overall, both facilitation and rapid depression were altered by the IM-AA mutation to similar extents in SC-CA1 synapses from our previous work (Nanou et al., 2016a) and in the SC-PV synapses studied here (see Fig. 4). Thus, in contrast to previous examples where the postsynaptic cell controlled presynaptic function (Koester and Johnston, 2005; Patel et al., 2013), these data show that the profile of short-term synaptic plasticity at these two SC synapses is similar despite their very different postsynaptic partners, suggesting that $\mathrm{CaS}$ proteins and $\mathrm{Ca}_{\mathrm{V}} 2.1$ channels are the primarily determinants of short-term plasticity at these synapses.

\section{Specific block of facilitation mediated by local $\mathrm{Ca}^{2+}$ transients}

Basal synaptic function can be assessed from the size and kinetics of a single EPSC and the frequency and amplitude of spontaneous miniature synaptic events resulting from release of a single synaptic vesicle (Katz, 1966). At the CA3-CA1 pyramidal cell synapse, the rate of rise, amplitude, and decay of the EPSC is unchanged in IM-AA mice (Nanou et al., 2016a). Similarly, the frequency and amplitude of miniature EPSCs, as measured in the presence of tetrodotoxin to block synaptic transmission initiated by action potentials and calcium channels, is unchanged in IM-AA mice (Nanou et al., 2016a). Together, these results from recordings of single EPSCs and miniature EPSCs support the conclusion that the function of the release machinery in the presynaptic terminal and both the distance and function of the AMPA subtype of glutamate receptors in the postsynaptic membrane are normal in IM-AA mice.

Facilitation in response to rapid, local $\mathrm{Ca}^{2+}$ transients in SCCA1 synapses is caused by binding of local $\mathrm{Ca}^{2+}$ to $\mathrm{CaS}$ proteins and the resulting facilitation of P/Q-type $\mathrm{Ca}^{2+}$ currents conducted by $\mathrm{Ca}_{\mathrm{V}} 2.1$ channels (Nanou et al., 2016a). To examine whether synaptic facilitation in SC-PV synapses also results from rapid, local increases in $\mathrm{Ca}^{2+}$, we applied the membrane-permeant reagent EGTA-AM, which releases the chelator EGTA inside cells and eliminates global $\mathrm{Ca}^{2+}$ increases without affecting rapid, lo$\mathrm{cal} \mathrm{Ca}^{2+}$ transients (Fig. 3A; Adler et al., 1991). Application of EGTA-AM $(100 \mu \mathrm{M})$ decreased evoked EPSC amplitudes in both WT and IM-AA synapses to a similar extent under basal conditions (Fig. $3 B$ ). This result indicates that the diffusion distance between the source of $\mathrm{Ca}^{2+}$ entry at the mouth of presynaptic $\mathrm{Ca}_{\mathrm{V}} 2.1$ channels and the $\mathrm{Ca}^{2+}$ binding sites on the presynaptic release machinery is unchanged in IM-AA synapses.

In contrast to the normal function of basal neurotransmission, the presence of EGTA-AM nearly completely abolished paired-pulse facilitation in SC-PV synapses from IM-AA mice (Fig. $3 A, C$ ). Thus, paired-pulse facilitation mediated by local increases in $\mathrm{Ca}^{2+}$ is nearly completely dependent upon $\mathrm{CaS}$ protein regulation of $\mathrm{Ca}_{\mathrm{V}} 2.1$ channels in SC-PV excitatory synapses. These results define a specific role for this form of $\mathrm{Ca}^{2+}$ channel regulation in local $\mathrm{Ca}^{2+}$ signaling that triggers short-term synaptic facilitation.

\section{Short-term synaptic plasticity in an inhibitory synapse}

Because short-term plasticity is less studied in inhibitory synapses, we assessed the role of $\mathrm{CaS}$ protein regulation of $\mathrm{Ca}_{\mathrm{V}} 2.1$ channels as a potential molecular mechanism for short-term plasticity in the inhibitory synapses formed by PV-expressing basket cells on CA1 pyramidal neurons (PV-CA1 synapses). IPSCs were evoked by pairs of depolarizing stimuli at different ISIs (Fig. $4 A, C)$. Inhibitory neurotransmission from PV interneurons to CA1 pyramidal neurons initiated by $\mathrm{Ca}_{\mathrm{V}} 2.1$ channels was isolated by addition of $\omega$-Ctx to block synaptic transmission initiated by $\mathrm{Ca}_{\mathrm{V}} 2.2$ channels in other interneuron types (e.g., CCK; Vinet and Sík, 2006; Lee and Soltesz, 2011). In contrast to excitatory synapses, the PV-CA1 synapse exhibits only synaptic depression at ISIs from 20 to $200 \mathrm{~ms}$ (Fig. 4C, black). Remarkably, this rapid synaptic depression is reversed in IM-AA synapses across the full range of ISIs tested (Fig. $4 C$, red). Therefore, these results lead to the surprising conclusion that $\mathrm{Ca}_{\mathrm{V}} 2.1$ channel regulation by $\mathrm{CaS}$ proteins is required for rapid synaptic depression in these WT inhibitory synapses in the absence of any detectable synaptic facilitation.

To assure that these synaptic properties were specifically characteristic of PV-CA1 synapses, we also stimulated synaptic trans- 
A

Electrical Stimulation

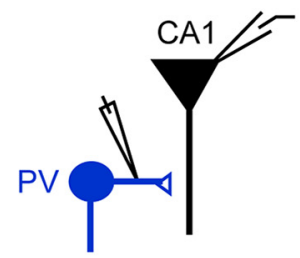

C
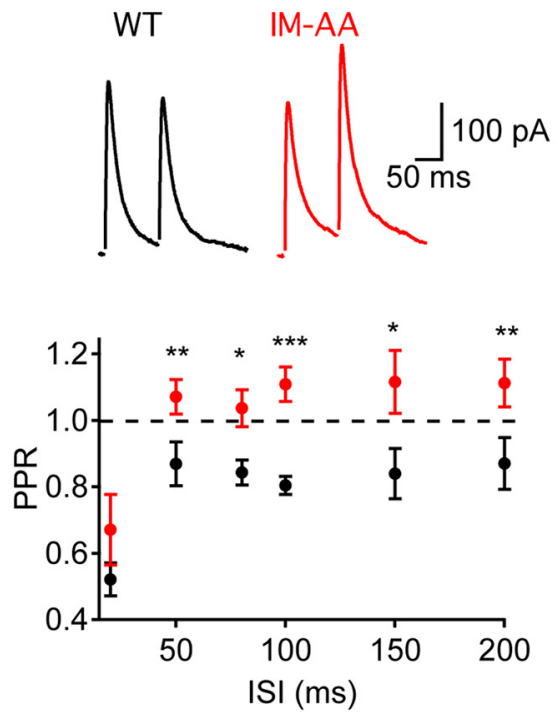

E
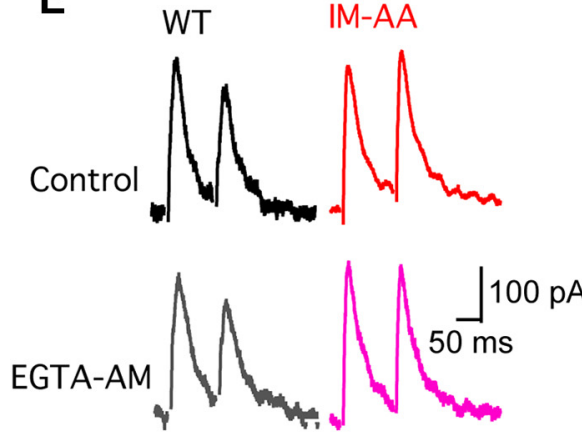

$\mathbf{F}$

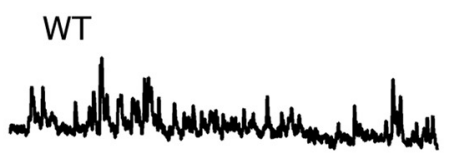

IM-AA

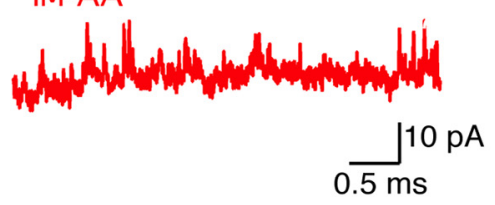

B

Optical Stimulation

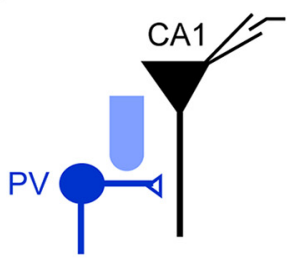

D

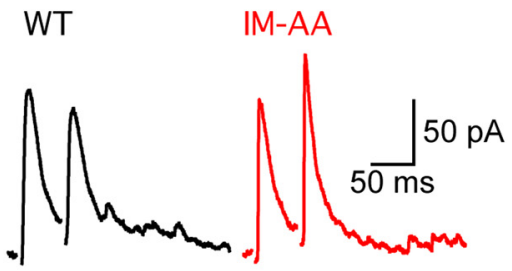

mission using a cell-specific optogenetic approach (Fig. 4B). Optical stimulation of PV interneurons was accomplished using mice that express Cre recombinase and channelrhodopsin under the control of the PV promoter. As with electrical stimulation of these WT synapses, rapid synaptic depression dominates at all ISIs tested (Fig. 4D, black), and the IM-AA mutation abolished rapid synaptic depression at ISIs from 50 to $200 \mathrm{~ms}$ (Fig. $4 D$, red). These results further support the conclusion that rapid synaptic depression at the inhibitory synapse of PV-expressing basket cells onto CA1 neurons in the hippocampus is mediated by $\mathrm{CaS}$ protein regulation of the inactivation of $\mathrm{Ca}_{\mathrm{V}} 2.1$ channels.

In contrast to the strong dependence of synaptic facilitation on local $\mathrm{Ca}^{2+}$ transients in excitatory synapses, we found that rapid synaptic depression is unaffected by EGTA-AM in PV-CA1 inhibitory synapses (Fig. 4E). This result is consistent with prior studies showing that facilitation of $\mathrm{Ca}_{\mathrm{V}} 2.1$ channels requires local $\mathrm{Ca}^{2+}$ signaling, whereas $\mathrm{Ca}^{2+}$-dependent inactivation of $\mathrm{Ca}_{\mathrm{V}} 2.1$ channels that contributes to rapid depression requires more long-lasting, global $\mathrm{Ca}^{2+}$ transients (Lee et al., 2000, 2003; DeMaria et al., 2001). As for excitatory synapses, measurements of miniature IPSCs (Fig. 4F) showed no effects of the IM-AA mutation on either frequency or amplitude, indicating that the basal function of these inhibitory synapses is unaffected by the IM-AA mutation. These data further support the conclusion that $\mathrm{CaS}$ protein regulation of $\mathrm{Ca}_{\mathrm{V}} 2.1$ channels contributes specifically to the rapid phase of depression at this synapse without significant effects on other aspects of synaptic function.

\section{Role of CaBP1/caldendrin in setting short-term synaptic plasticity at an inhibitory synapse in vivo}

There is a large family of CaS proteins (Haeseleer and Palczewski, 2002); however, only CaBP1 has been found to block facilitation and enhance inactivation of $\mathrm{Ca}^{2+}$ currents conducted by $\mathrm{Ca}_{\mathrm{V}} 2.1$ channels (Lee et al., 2002). CaBP1 and calden-

PPR of inhibitory IPSCs in absence (control) and presence of EGTA-AM from WT (Control, black, $n=14$ cells; EGTA-AM, gray, $n=5$ cells) and IM-AA (Control, red, $n=11$ cells, 4 animals; EGTA-AM, pink, $n=5$ ) (A1 pyramidal neurons $\boldsymbol{F}$, Example traces and average miniature IPSC amplitude (Amp), frequency (Freq), rise time (Rise), and decay time (Decay) from WT $(n=8)$ and IM-AA $(n=7)$. Recordings were made in the presence of $1 \mu \mathrm{m} \omega$-Ctx, $50 \mu \mathrm{m}$ APV, and $20 \mu \mathrm{m}$ CNQX.

Figure 4. IM-AA mutation abolishes paired-pulse depression in inhibitory synapses. Schematics of recording inhibitory synaptic transmission onto CA1 pyramidal neurons by $(\boldsymbol{A})$ electrical or $(\boldsymbol{B})$ optical stimulation of stratum pyramidale interneurons. C, Example evoked IPSCs from CA1 pyramidal neurons from WT (black) and IM-AA (red) mice in response to electrical stimulation of PV interneurons. PPR plotted as a function of ISI from WT (black; $n=7$ cells) and IM-AA (red; $n=8$ cells). ${ }^{* *} p=0.01$, ISI $=50$ $\mathrm{ms}^{*}{ }^{*} p=0.03, \mathrm{ISI}=80 \mathrm{~ms} ;{ }^{* * *} p=2.70 \mathrm{E}-05, \mathrm{ISI}=100 \mathrm{~ms} ;{ }^{*} p=0.03, \mathrm{ISI}=150 \mathrm{~ms} ;{ }^{* *} p=0.03, \mathrm{ISI}=200 \mathrm{~ms}$. D, Example evoked IPSCs from CA1 pyramidal neurons from WT (black) and IM-AA (red) mice in response to optical stimulation of PV interneurons. PPR plotted as a function of ISI from WT (black; $n=9$ cells) and IM-AA (red; $n=18$ cells). ${ }^{* *} p=0.006, I S I=50$ ms; ${ }^{*} p=$ $0.04, I S\left|=80 \mathrm{~ms} ;{ }^{*} p=0.008, I S\right|=100 \mathrm{~ms} ;{ }^{*} p=0.05, I S I=150 \mathrm{~ms} ;{ }^{*} p=0.006, I S \mid=200 \mathrm{~ms}$. $E$, Example traces and average 
A

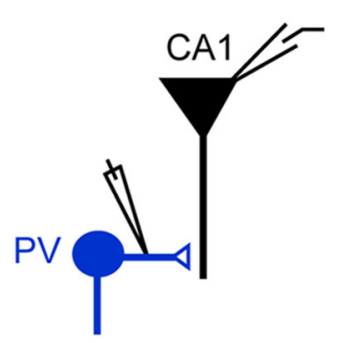

B

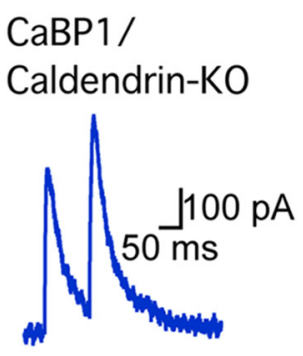

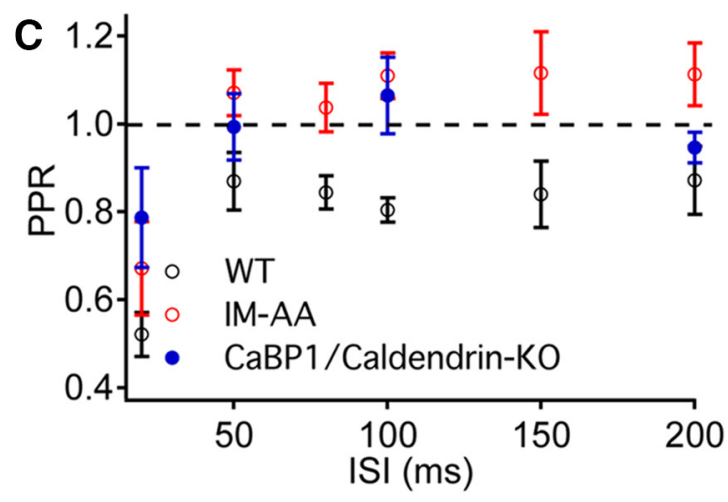

E

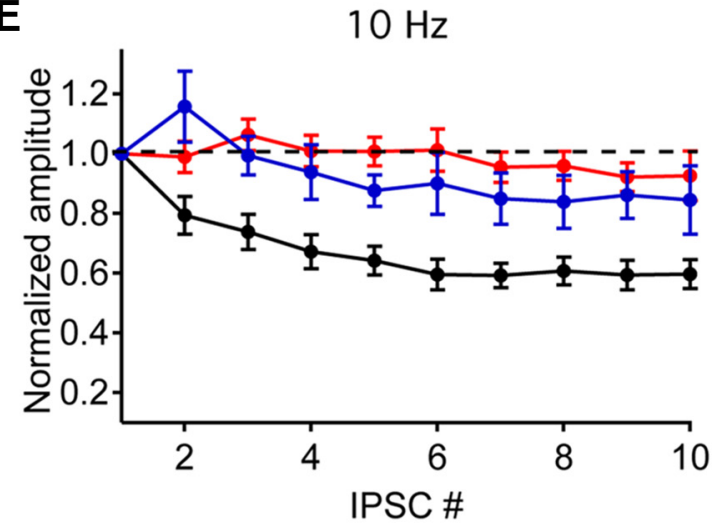

G

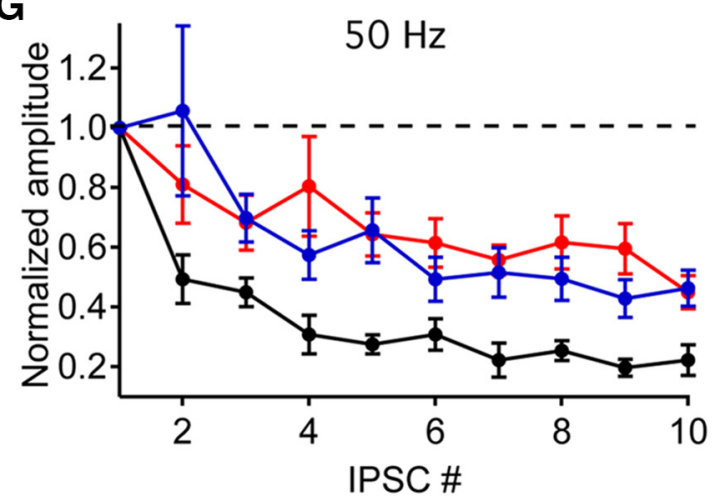

Figure 5. CaBP1/caldendrin-K0 impairs synaptic depression in PV-CA1 synapses. $\boldsymbol{A}$, Schematic of recording inhibition from a CA1 pyramidal neuron. $\boldsymbol{B}$, Example evoked paired IPSCs from CaBP1/caldendrin-KO PV-CA1 synapses. C, PPR plotted as a function of ISI from CA1 pyramidal neurons from WT (black; $n=7$ ), IM-AA (red; $n=8$ ) and CaBP1/caldendrin-K0 (blue; $n=12$ ) mice.

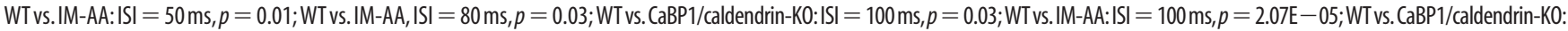
$I S I=100 \mathrm{~ms}, p=0.04$; WT vs. IM-AA: ISI = $150 \mathrm{~ms}, p=0.03$; WT vs. IM-AA:ISI $=200 \mathrm{~ms}, p=0.003 ;$ IM-AA vs. CaBP1/caldendrin-K0: ISI = 100 ms, $p=0.008 . \boldsymbol{D}, \boldsymbol{E}$, Average normalized peak amplitude of evoked IPSCs during trains from CA1 pyramidal neurons from WT (black), IM-AA (red), and CaBP1/caldendrin KO (blue) mice in response to electrical stimulation of PV interneurons. D, $5 \mathrm{~Hz}$ : WT, $n=8$; IM-AA, $n=9 ; \mathrm{CaBP} 1 /$ caldendrin-K0, $n=10 ; \mathrm{WT}$ vs. CaBP1/caldendrin-K0, $p=0.0001 . \boldsymbol{E}, 10 \mathrm{~Hz}: \mathrm{WT}, n=8 ; \mathrm{IM}-\mathrm{AA}, n=9 ;$ CaBP1/caldendrin-KO, $n=10 ; \mathrm{WT}$ vs. CaBP1/caldendrin-KO, $p=0.0001 . \boldsymbol{F}, 20 \mathrm{~Hz}: \mathrm{WT}, n=$ 8; IM-AA, $n=8 ;$ CaBP1/caldendrin-K0, $n=9$; WT vs. CaBP1/caldendrin-K0, $p=0.0001$. G, 50 Hz: WT, $n=9 ;$ IMA-A, $n=8 ;$ CaBP1/caldendrin-K0, $n=7$; WT vs. CaBP1/caldendrin-K0, $p=0.0001$. All recordings were made in the presence of $1 \mu \mathrm{m} \omega$-Ctx, $50 \mu \mathrm{m} \mathrm{APV}$, and $20 \mu \mathrm{m}$ CNQX.

drin are alternative splice products of the same gene (Haeseleer and Palczewski, 2002). Provocatively, PV interneurons express a high level of CaBP1/caldendrin (Kim et al., 2014). Therefore, we examined whether targeted deletion of the first two protein-coding exons of the gene encoding $\mathrm{CaBP} 1 /$ caldendrin in mice (Kim et al., 2014) alters short-term depression at inhibitory PV-CA1 synapses (Fig. 5A). We found that rapid short-term depression caused by paired-pulse stimuli in WT mice (Fig. 5C, black) was completely prevented in synapses from CaBP1/caldendrin knock-out mice at ISIs from 50 to $200 \mathrm{~ms}$ (Fig. 5C, blue), just as we observed in IM-AA mice (Fig. $5 C$, red). These results directly implicate regulation of
$\mathrm{Ca}_{\mathrm{V}} 2.1$ channel inactivation by $\mathrm{CaBP} 1 /$ caldendrin in the rapid synaptic depression that is characteristic of this synapse.

To examine these effects in a more physiological repetitivepulsing paradigm, we studied synaptic transmission in response to trains of stimuli from 5 to $50 \mathrm{~Hz}$ (Fig. 5D-G). Rapid depression was observed in WT synapses (Fig. 5D-G, black). However, the rapid phase of depression from 50 to $200 \mathrm{~ms}$ was much less prominent in the $\mathrm{CaBP} 1 /$ caldendrin knock-out synapses compared with WT (Fig. 5D-G, blue; $p=0.0001$ ). This observed impairment in the rapid phase of synaptic depression was similar to the effects of the IM-AA mutation (Fig. 5D-G, red). Importantly, the IM-AA mu- 
A
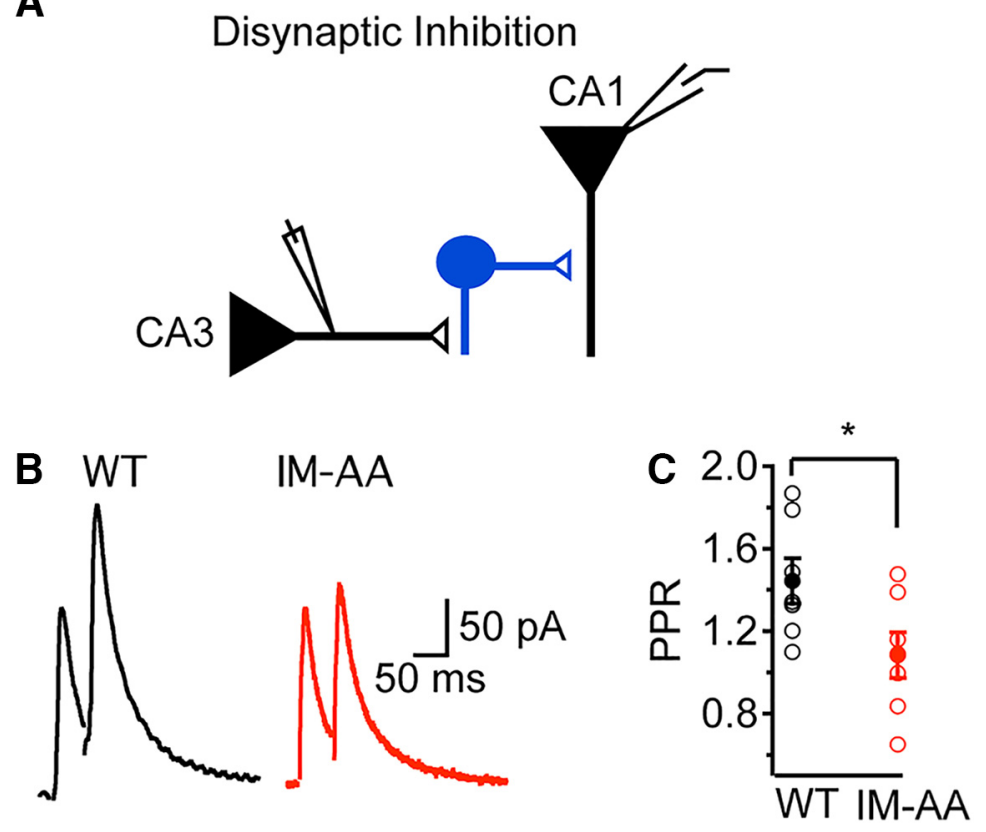

Figure 6. IM-AA mutation reduces paired-pulse facilitation in disynaptic neurotransmission. $\boldsymbol{A}$, Schematic of recording disynaptic inhibition from CA1 pyramidal neuron. $B$, Example evoked IPSCs from WT CA1 pyramidal (black) and IM-AA (red) CA1 pyramidal neurons in response to paired-pulse stimulation of $\mathrm{SC}$ fibers. Stimulus artifacts were blanked for clarity. Disynaptic transmission was isolated by selecting only IPSCs having a latency of $\geq 7 \mathrm{~ms}$ compared with $4 \mathrm{~ms}$ for monosynaptic transmission. C, PPR plotted as a function of $50 \mathrm{~ms}$ ISI from WT (black; $n=7$ cells) and IM-AA (red; $n=7$ cells) CA1 pyramidal neurons. All recordings were made in the presence of $1 \mu \mathrm{m} \omega$-Ctx and $50 \mu \mathrm{M} A P V .{ }^{*} p=0.04$.

tation in $\mathrm{Ca}_{\mathrm{V}} 2.1$ channels and the CaBP1/caldendrin knock-out both reduced and slowed short-term depression to similar extents, altering the frequency-dependent information processing in response to trains of action potentials in PV-CA1 synapses. Together, these results demonstrate that regulation of $\mathrm{Ca}_{\mathrm{V}} 2.1$ channels by $\mathrm{CaBP} 1 /$ caldendrin is required for the dominance of rapid shortterm depression at this important hippocampal synapse.

\section{Effects of short-term synaptic plasticity on E/I ratio in a local hippocampal circuit}

Alterations in the plasticity of hippocampal excitatory and inhibitory synapses by $\mathrm{CaS}$ protein regulation of $\mathrm{Ca}_{\mathrm{V}} 2.1$ channels could result in impairments in hippocampal circuit function. To test the effects of this regulatory mechanism on the disynaptic pathway from CA3 pyramidal cells to PV-expressing interneurons to CA1 pyramidal neurons, we recorded disynaptic inhibition in response to SC stimulation. We found that paired-pulse facilitation of disynaptic inhibition was nearly completely blocked by the IM-AA mutation (Fig. 6). Unexpectedly, these results reveal that the overall impact of the IM-AA mutation on excitatory and inhibitory transmission in this disynaptic pathway is to greatly reduce paired-pulse facilitation of the inhibitory input to CA1 pyramidal neurons, demonstrating that loss of rapid depression at the inhibitory PV-to-CA1 pyramidal neuron synapse dominates over loss of facilitation at the CA3-to-PV synapse.

Preferential impairment of synaptic inhibition by the IM-AA mutation raises the possibility that $\mathrm{CaS}$ protein regulation of $\mathrm{Ca}_{\mathrm{V}} 2.1$ channels might control the $\mathrm{E} / \mathrm{I}$ ratio in the parallel monosynaptic and disynaptic pathways from CA3 to CA1 pyramidal neurons. To assess the overall impact of the IM-AA mutation in setting the balance of excitatory to inhibitory neurotransmission in these parallel synaptic pathways, we tested its effect on paired compound EPSC/IPSCs elicited by stimulation of CA3 pyramidal neurons and recorded in CA1 pyramidal neurons. This experiment directly compares the strength of synaptic input to the CA1 pyramidal neuron by the direct excitatory monosynaptic pathway to the indirect inhibitory disynaptic pathway via PV interneurons. We found that WT synapses exhibited greater facilitation in the excitatory component of the paired compound EPSC/ IPSCs, as indicated by the larger negative deflection of the EPSC (Fig. $7 A$, red) compared with the IPSC (Fig. 7A, blue). The PPR for excitation was significantly greater than for inhibition (Fig. 7B), consistent with our previous experiments (Figs. 1, 4). The IM-AA mutation reduced the amplitude of the EPSC, but the reduction in the IPSC was much greater (Fig. $7 A$ ). These changes resulted in a more substantial reduction in paired-pulse facilitation for excitation compared with paired-pulse facilitation for inhibition (Fig. $7 B$ ). The E/I ratio was strikingly changed by the IM-AA mutation (Fig. 7C, left). For WT, the E/I ratio was $2.1 \pm 0.7$ in Pulse 1 and increased to $2.9 \pm 0.8$ in Pulse 2 (Fig. 7C, left). In contrast, for IM-AA, the $\mathrm{E} / \mathrm{I}$ ratio was $13.3 \pm 8.0$ in Pulse 1 and increased to $29.0 \pm 7.8$ in Pulse 2 (Fig. 7C, left). A similar large increase in $\mathrm{E} / \mathrm{I}$ ratio was observed when we calculated the E/I ratio from the integrated area under the EPSC/IPSC curves rather than from the peak amplitude (Fig. $7 C$, right). Evidently, block of regulation of $\mathrm{Ca}_{\mathrm{V}} 2.1$ channels by $\mathrm{CaS}$ proteins dramatically alters the $\mathrm{E} / \mathrm{I}$ ratio in favor of excitation in these opposing synaptic pathways that control the input/output function of CA1 pyramidal neurons.

Together, our results show that $\mathrm{CaS}$ protein regulation of $\mathrm{Ca}_{\mathrm{v}} 2.1$ channels dominates in determining the level of facilitation or depression of inhibitory transmission in this local circuit and thereby dominates in setting the E/I ratio in these two opposing synaptic pathways. The level of CaS protein-dependent facilitation of $\mathrm{Ca}_{\mathrm{V}} 2.1$ channels increases excitatory synaptic transmission in the SC-CA1 excitatory synapse, but CaBP1-dependent inactivation of $\mathrm{Ca}_{\mathrm{v}} 2.1$ channels has an even stronger effect to prevent facilitation and accelerate rapid depression in the inhibitory PV-CA1 synapse. Loss of this $\mathrm{CaS}$ protein regulation of $\mathrm{Ca}_{\mathrm{V}} 2.1$ channels in IM-AA mice leads to greater loss of inhibitory neurotransmission and a large increase in $\mathrm{E} / \mathrm{I}$ ratio. Thus, this regulatory process differentially controls the direction of short-term synaptic plasticity in excitatory and inhibitory neurons in this local circuit and sets its E/I ratio at the CA1 pyramidal cell. Because CA1 pyramidal neurons are the major output pathway of the hippocampus, these large changes in E/I ratio would have profound effects on brain function.

\section{Discussion}

\section{Basal function is normal in IM-AA} synapses

Our studies of neuromuscular synapses (Nanou et al., 2016b) and four hippocampal synapses [autaptic (Nanou et al., 2016a), CA3CA1 (Nanou et al., 2016a), CA3-PV and PV-CA1 (studied here)] provide strong support for the conclusion that basal synaptic function is not altered by the IM-AA mutation. Results from evoked PSCs and spontaneous miniature PSCs indicate that a similar 
amount of neurotransmitter (acetylcholine, glutamate, or GABA) is released presynaptically, the diffusion time to the postsynaptic site is unaltered, and the postsynaptic receptor is activated normally. In CA3-CA1 synapses and CA3-PV synapses, we found that treatment with EGTA-AM caused the same reduction in peak amplitude of EPSCs in WT and IM-AA synapses. These results show that chelation of intracellular $\mathrm{Ca}^{2+}$ by EGTA released from EGTA-AM has the same impact in WT and IM-AA synapses, supporting the conclusion that the diffusion distance from the point of $\mathrm{Ca}^{2+}$ entry at the intracellular mouth of the $\mathrm{Ca}_{\mathrm{V}} 2.1$ channel to the calcium sensors in the release machinery is unchanged. Thus, the IM-AA mutation has surprisingly little effect on the basal function of excitatory or inhibitory synapses.

Two excitatory synapses formed by CA3 neurons have identical short-term plasticity

Short-term synaptic plasticity is caused by $\mathrm{Ca}^{2+}$-dependent modulation of the function of the presynaptic terminal; however, it is not known in general whether shortterm synaptic plasticity at multiple types of presynaptic terminals formed by the same neuron is identical or is controlled by the postsynaptic neuron. Although several examples demonstrate that the postsynaptic neuron can have an important effect on presynaptic function and plasticity (Koester and Johnston, 2005; Patel et al., 2013), our results show that the two major classes of synapses formed by CA3 neurons on excitatory CA1 neurons and on inhibitory PV neurons are identical in their short-term synaptic plasticity. Moreover, the effects of the IM-AA mutation are identical in these two classes of synapses. Evidently, the functional role of CaS protein modulation of $\mathrm{Ca}_{\mathrm{V}} 2.1$ channels in synaptic facilitation and rapid depression is identical in these two types of excitatory synapses formed by presynaptic terminals of CA3 pyramidal neurons.

\section{Distinct pattern of short-term synaptic plasticity at an inhibitory} nerve terminal

In sharp contrast to our results with two excitatory synapses formed by CA3 pyramidal neurons, the PV-CA1 inhibitory synapse has a very different pattern of short-term synaptic plasticity and a different contribution of regulation of $\mathrm{Ca}_{\mathrm{V}} 2.1$ channels by $\mathrm{CaS}$ proteins. This synapse is crucial in hippocampal function, as the firing of these PV interneurons is required for spike timingdependent synaptic plasticity and for generation of sharp-wave ripples (Buzsáki, 2015). As reported previously (Bartley and Dobrunz, 2015), the PV-CA1 synapse exhibits only rapid depression in response to paired stimuli or trains of stimuli. Remarkably, we
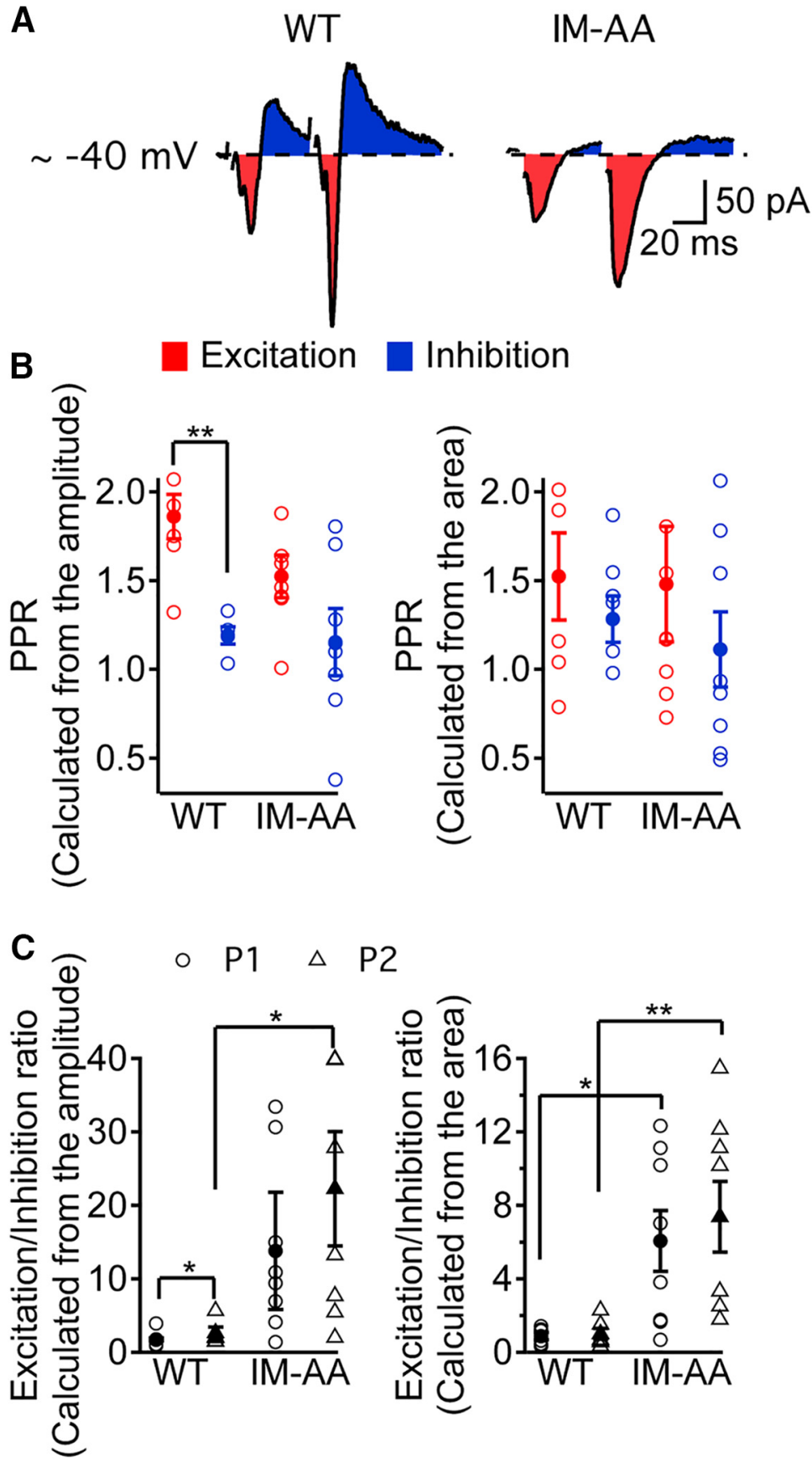

Figure 7. IM-AA mutation greatly increases the excitation to inhibition ratio in SC-CA1 synapses. $A$, Example evoked compound PSCs from WT (left) and IM-AA (right) CA1 pyramidal neurons. B, PPR of excitation (red) and inhibition (blue) from WT ( $n=5, p=$ $0.001)$ and IM-AA ( $n=8, p=0.08$, n.s.) at $50 \mathrm{~ms} \mathrm{ISI} \mathrm{calculated} \mathrm{from} \mathrm{either} \mathrm{the} \mathrm{peak} \mathrm{amplitude} \mathrm{(left)} \mathrm{or} \mathrm{the} \mathrm{integrated} \mathrm{area} \mathrm{under}$ the curve (right). C, Ratio of E/I plotted for Pulse 1 (circle) and Pulse 2 (triangle) calculated from either peak amplitude (left; WT P1 vs WT P2, ${ }^{*} p=0.05 ;$ WT P2 vs IM-AA P2, ${ }^{*} p=0.02$ ) or integrated area (right; WT P1 vs IM-AA P1, ${ }^{*} p=0.02 ;$ WT P2 vs IM-AA P2, ${ }^{* *} p=0.01$ ). All recordings were made in the presence of $1 \mu \mathrm{m} \omega$-Ctx or $50 \mu \mathrm{m} \mathrm{APV}$.

found that the IM-AA mutation completely blocks the characteristic rapid depression at this synapse. These results indicate that enhanced inactivation of $\mathrm{Ca}_{\mathrm{V}} 2.1$ channels by a CaS protein is responsible for the rapid depression observed at the critically important PV-CA1 synapse in the hippocampus.

Regulation of short-term synaptic plasticity at an inhibitory synapse by CaBP1

Of the $\mathrm{CaS}$ proteins studied to date, only $\mathrm{CaBP} 1$ blocks facilitation of $\mathrm{Ca}_{\mathrm{V}} 2.1$ channels and enhances inactivation of their P/Q- 
type $\mathrm{Ca}^{2+}$ current (Lee et al., 2002). Expression of CaBP1 with $\mathrm{Ca}_{\mathrm{V}} 2.1$ in presynaptic superior cervical ganglion neurons blocks $\mathrm{Ca}_{\mathrm{V}}$ 2.1-dependent facilitation and enhances rapid synaptic depression (Leal et al., 2012). Because CaBP1/caldendrin is highly expressed in PV basket cells in the hippocampus (Kim et al., 2014), this $\mathrm{CaS}$ protein was a strong candidate for inducing enhanced inactivation of $\mathrm{Ca}_{\mathrm{V}} 2.1$ channels and rapid synaptic depression at the PV-CA1 synapse. Deletion of the first two protein-coding exons of this gene effectively deletes both CaBP1 and caldendrin (Kim et al., 2014). Remarkably, deletion of these exons completely prevents rapid synaptic depression at this synapse. Evidently, the increased rate of inactivation of $\mathrm{Ca}_{\mathrm{V}} 2.1$ channels caused by $\mathrm{CaBP} 1 /$ caldendrin is entirely responsible for the rapid phase of depression in PV-CA1 synapses. These unexpected results give the first evidence that $\mathrm{CaS}$ proteins can set the overall direction of short-term synaptic plasticity at a native synapse in vivo.

\section{Control of local circuit function by regulation of presynaptic $\mathrm{Ca}^{2+}$ channels}

The CA3, PV, and CA1 cells form a crucial local circuit in the hippocampus (Paulsen and Moser, 1998). CA3 pyramidal neurons innervate CA1 pyramidal neurons directly and provide powerful glutamatergic excitatory drive that stimulates action potential firing. In parallel, CA3 pyramidal neurons innervate inhibitory PV basket cells and excite their action potential firing, which in turn activates GABAergic neurotransmission at the PVCA1 synapse and exerts a powerful inhibitory effect on action potential firing by CA1 neurons. The balance of excitation and inhibition of this local circuit in large part controls the input/ output function of the hippocampus. Unexpectedly, we found dramatic effects of the IM-AA mutation on E/I ratio in this local circuit. Reduction of disynaptic inhibition via the CA3-PV-CA1 pathway greatly exceeded the effects of delayed facilitation in the CA3-CA1 direct monosynaptic excitatory pathway, resulting in up to 10 -fold increase in E/I ratio in IM-AA mice. Such a large change in $\mathrm{E} / \mathrm{I}$ ratio in this important circuit would have major impacts on encoding and transmitting information in the hippocampus.

\section{$\mathrm{Ca}_{\mathrm{v}}$ 2.1 regulation, altered circuit function, and spatial learning and memory}

Surprisingly, IM-AA mice have decreased sensitivity for generation of long-term potentiation at the CA3-CA1 synapses in the hippocampus and dramatically impaired spatial learning and memory (Nanou et al., 2016c). Our studies of synapse and circuit function in the hippocampus now provide potential points of linkage to these previously described deficits. First, the striking changes in short-term synaptic plasticity at the CA1-PV synapse would likely alter sharp-wave ripples and thereby impair spatial learning and memory (Buzsáki, 2015). The successive depolarizations within a sharp-wave ripple take place on the 5 to $10 \mathrm{~ms}$ time scale, similar to synaptic facilitation and rapid depression, and they are critically dependent on action potentials of PV basket cells. Impairment of short-term plasticity of CA3-PV synapses by the IM-AA mutation would be likely to alter critical aspects of the timing of sharp-wave ripple generation. Second, the dramatic increase in $\mathrm{E} / \mathrm{I}$ ratio in the local circuit controlling CA1 excitability would be expected to generate homeostatic changes in excitability of the CA1 neurons to compensate for the increased E/I ratio of their incoming synaptic activity (Turrigiano, 2008). Whereas the basal function of these synapses measured from the fast EPSCs mediated by AMPA-type glutamate receptors is normal, we found that the slower responses of the postsynaptic NMDA-type glutamate receptors is sharply reduced (Nanou et al., 2016c). This homeostatic change would be sufficient to impair long-term potentiation and the formation and stability of place cells, which are crucial for spatial learning and memory (Buzsáki and Moser, 2013), because $\mathrm{Ca}^{2+}$ entry via NMDA-type glutamate receptors is an important trigger for long-term potentiation. Such large changes in the balance of excitatory and inhibitory synapses could result in impairments in encoding spatial information in the hippocampus (Klyachko and Stevens, 2006). Discovering the underlying mechanisms for balancing the plasticity of excitatory and inhibitory inputs is an important first step in understanding the functional roles of synaptic facilitation and rapid synaptic depression in hippocampal circuits. In vivo recordings from IM-AA mice while performing spatial learning tasks will provide a concrete understanding of the role of short-term plasticity in hippocampal circuit function and spatial learning. Future studies of the function of the larger neural circuits that generate sharp-wave ripples and place cells may reveal how these alterations in short-term and long-term synaptic plasticity intersect to impair spatial learning in IM-AA mice.

\section{Presynaptic plasticity and disease}

Beyond its key role in encoding and transmitting information contained in the frequency and pattern of action potential generation in trains, short-term synaptic facilitation is also implicated in neurological disease. For example, alterations in facilitation of $\mathrm{Ca}_{\mathrm{V}} 2.1$ channels cause familial hemiplegic migraine (Tottene et al., 2002; Adams et al., 2010; Vecchia et al., 2014, 2015), in which mutations cause permanent facilitation of channel function and occlude further upregulation by repetitive firing of action potentials. Our results point to the possibility that mutation or altered regulation of $\mathrm{Ca}_{\mathrm{V}} 2.1$ channels by $\mathrm{CaS}$ proteins may impair spatial learning in other neurological diseases as well.

\section{References}

Abbott LF, Regehr WG (2004) Synaptic computation. Nature 431:796-803. CrossRef Medline

Adams PJ, Rungta RL, Garcia E, van den Maagdenberg AM, MacVicar BA, Snutch TP (2010) Contribution of calcium-dependent facilitation to synaptic plasticity revealed by migraine mutations in the P/Q-type calcium channel. Proc Natl Acad Sci U S A 107:18694-18699. CrossRef Medline

Adler EM, Augustine GJ, Duffy SN, Charlton MP (1991) Alien intracellular calcium chelators attenuate neurotransmitter release at the squid giant synapse. J Neurosci 11:1496-1507. CrossRef Medline

Anwar H, Li X, Bucher D, Nadim F (2017) Functional roles of short-term synaptic plasticity with an emphasis on inhibition. Curr Opin Neurobiol 43:71-78. CrossRef Medline

Bartley AF, Dobrunz LE (2015) Short-term plasticity regulates the excitation/inhibition ratio and the temporal window for spike integration in CA1 pyramidal cells. Eur J Neurosci 41:1402-1415. CrossRef Medline

Borst JG, Sakmann B (1998) Facilitation of presynaptic calcium currents in the rat brainstem. J Physiol 513:149-155. CrossRef Medline

Buzsáki G (2015) Hippocampal sharp wave-ripple: a cognitive biomarker for episodic memory and planning. Hippocampus 25:1073-1188. CrossRef Medline

Buzsáki G, Moser EI (2013) Memory, navigation and theta rhythm in the hippocampal-entorhinal system. Nat Neurosci 16:130-138. CrossRef Medline

Catterall WA (2011) Voltage-gated calcium channels. Cold Spring Harb Perspect Biol 3:a003947. CrossRef Medline

Catterall WA, Few AP (2008) Calcium channel regulation and presynaptic plasticity. Neuron 59:882-901. CrossRef Medline

Catterall WA, Leal K, Nanou E (2013) Calcium channels and short-term synaptic plasticity. J Biol Chem 288:10742-10749. CrossRef Medline

Cuttle MF, Tsujimoto T, Forsythe ID, Takahashi T (1998) Facilitation of the presynaptic calcium current at an auditory synapse in rat brainstem. J Physiol 512:723-729. CrossRef Medline

DeMaria CD, Soong TW, Alseikhan BA, Alvania RS, Yue DT (2001) Calmodulin bifurcates the local $\mathrm{Ca}^{2+}$ signal that modulates $\mathrm{P} / \mathrm{Q}-$ type $\mathrm{Ca}^{2+}$ channels. Nature 411:484-489. CrossRef Medline 
Dunlap K, Luebke JI, Turner TJ (1995) Exocytotic calcium channels in mammalian central neurons. Trends Neurosci 18:89-98. CrossRef Medline

Forsythe ID, Tsujimoto T, Barnes-Davies M, Cuttle MF, Takahashi T (1998) Inactivation of presynaptic calcium current contributes to synaptic depression at a fast central synapse. Neuron 20:797-807. CrossRef Medline

Haeseleer F, Palczewski K (2002) Calmodulin and $\mathrm{Ca}^{2+}$-binding proteins (CaBPs): variations on a theme. Adv Exp Med Biol 514:303-317. CrossRef Medline

Inchauspe CG, Martini FJ, Forsythe ID, Uchitel OD (2004) Functional compensation of $\mathrm{P} / \mathrm{Q}$ by N-type channels blocks short-term plasticity at the calyx of held presynaptic terminal. J Neurosci 24:10379-10383. CrossRef Medline

Jackman SL, Regehr WG (2017) The mechanisms and functions of synaptic facilitation. Neuron 94:447-464. CrossRef Medline

Katz B (1966) Nerve, muscle, and synapse. New York; London: McGraw-Hill.

Kim KY, Scholl ES, Liu X, Shepherd A, Haeseleer F, Lee A (2014) Localization and expression of $\mathrm{CaBP} 1 /$ caldendrin in the mouse brain. Neuroscience 268:33-47. CrossRef Medline

Klyachko VA, Stevens CF (2006) Excitatory and feed-forward inhibitory hippocampal synapses work synergistically as an adaptive filter of natural spike trains. PLoS Biol 4:e207. CrossRef Medline

Koester HJ, Johnston D (2005) Target cell-dependent normalization of transmitter release at neocortical synapses. Science 308:863-866. CrossRef Medline

Lautermilch NJ, Few AP, Scheuer T, Catterall WA (2005) Modulation of $\mathrm{Ca}_{\mathrm{V}} 2.1$ channels by the neuronal calcium-binding protein visinin-like protein-2. J Neurosci 25:7062-7070. CrossRef Medline

Leal K, Mochida S, Scheuer T, Catterall WA (2012) Fine-tuning short-term synaptic plasticity via regulation of presynaptic calcium channels by calcium sensor proteins. Proc Natl Acad Sci U S A 109:17069-17074. CrossRef Medline

Lee A, Wong ST, Gallagher D, Li B, Storm DR, Scheuer T, Catterall WA (1999) $\mathrm{Ca}^{2+} /$ calmodulin binds to and modulates P/Q-type calcium channels. Nature 399:155-159. CrossRef Medline

Lee A, Scheuer T, Catterall WA (2000) $\mathrm{Ca}^{2+} /$ calmodulin-dependent facilitation and inactivation of P/Q-type $\mathrm{Ca}^{2+}$ channels. J Neurosci 20:68306838. CrossRef Medline

Lee A, Westenbroek RE, Haeseleer F, Palczewski K, Scheuer T, Catterall WA (2002) Differential modulation of $\mathrm{Ca}_{\mathrm{V}} 2.1$ channels by calmodulin and $\mathrm{Ca}^{2+}$-binding protein 1. Nat Neurosci 5:210-217. CrossRef Medline

Lee A, Zhou H, Scheuer T, Catterall WA (2003) Molecular determinants of $\mathrm{Ca}^{2+} /$ calmodulin-dependent regulation of $\mathrm{Ca}_{\mathrm{v}} 2.1$ channels. Proc Natl Acad Sci U S A 100:16059-16064. CrossRef Medline

Lee SH, Soltesz I (2011) Requirement for CB1 but not $\mathrm{GABA}_{\mathrm{B}}$ receptors in the cholecystokinin mediated inhibition of GABA release from cholecystokinin expressing basket cells. J Physiol 589:891-902. CrossRef Medline

Mochida S, Few AP, Scheuer T, Catterall WA (2008) Regulation of presynaptic $\mathrm{Ca}_{\mathrm{V}} 2.1$ channels by $\mathrm{Ca}^{2+}$ sensor proteins mediates short-term synaptic plasticity. Neuron 57:210-216. CrossRef Medline

Mori Y, Friedrich T, Kim MS, Mikami A, Nakai J, Ruth P, Bosse E, Hofmann F, Flockerzi V, Furuichi T, Mikoshiba K, Imoto K, Tanabe T, Numa S (1991) Primary structure and functional expression from complementary DNA of a brain calcium channel. Nature 350:398-402. CrossRef Medline

Nanou E, Sullivan JM, Scheuer T, Catterall WA (2016a) Calcium sensor regulation of the $\mathrm{Ca}_{\mathrm{V}} 2.1 \mathrm{Ca}^{2+}$ channel contributes to short-term synaptic plasticity in hippocampal neurons. Proc Natl Acad Sci U S A 113:10621067. CrossRef Medline

Nanou E, Yan J, Whitehead NP, Kim MJ, Froehner SC, Scheuer T, Catterall WA (2016b) Altered short-term synaptic plasticity and reduced muscle strength in mice with impaired regulation of presynaptic $\mathrm{Ca}_{\mathrm{V}} 2.1 \mathrm{Ca}^{2+}$ channels. Proc Natl Acad Sci U S A 113:1068-1073. CrossRef Medline

Nanou E, Scheuer T, Catterall WA (2016c) Calcium sensor regulation of the $\mathrm{Ca}_{\mathrm{V}} 2.1$ channel contributes to long-term potentiation and spatial learning. Proc Natl Acad Sci U S A 113:13209-13214. CrossRef Medline

Patel AB, Hays SA, Bureau I, Huber KM, Gibson JR (2013) A target cellspecific role for presynaptic Fmr1 in regulating glutamate release onto neocortical fast-spiking inhibitory neurons. J Neurosci 33:2593-2604. CrossRef Medline

Paulsen O, Moser EI (1998) A model of hippocampal memory encoding and retrieval: GABAergic control of synaptic plasticity. Trends Neurosci 21:273-278. CrossRef Medline

Starr TV, Prystay W, Snutch TP (1991) Primary structure of a calcium channel that is highly expressed in the rat cerebellum. Proc Natl Acad Sci U S A 88:5621-5625. CrossRef Medline

Tottene A, Fellin T, Pagnutti S, Luvisetto S, Striessnig J, Fletcher C, Pietrobon D (2002) Familial hemiplegic migraine mutations increase $\mathrm{Ca}^{2+}$ influx through single human $\mathrm{Ca}_{\mathrm{V}} 2.1$ channels and decrease maximal $\mathrm{Ca}_{\mathrm{V}} 2.1$ current density in neurons. Proc Natl Acad Sci U S A 99:13284-13289. CrossRef Medline

Tsien RW, Lipscombe D, Madison D, Bley K, Fox A (1995) Reflections on $\mathrm{Ca}^{2+}$-channel diversity, 1988-1994. Trends Neurosci 18:52-54. CrossRef Medline

Tsujimoto T, Jeromin A, Saitoh N, Roder JC, Takahashi T (2002) Neuronal calcium sensor 1 and activity-dependent facilitation of P/Q-type calcium currents at presynaptic nerve terminals. Science 295:2276-2279. CrossRef Medline

Turrigiano GG (2008) The self-tuning neuron: synaptic scaling of excitatory synapses. Cell 135:422-435. CrossRef Medline

Vecchia D, Tottene A, van den Maagdenberg AM, Pietrobon D (2014) Mechanism underlying unaltered cortical inhibitory synaptic transmission in contrast with enhanced excitatory transmission in $\mathrm{Ca}_{\mathrm{V}} 2.1$ knockin migraine mice. Neurobiol Dis 69:225-234. CrossRef Medline

Vecchia D, Tottene A, van den Maagdenberg AM, Pietrobon D (2015) Abnormal cortical synaptic transmission in $\mathrm{Ca}_{\mathrm{v}} 2.1$ knockin mice with the S218L missense mutation which causes a severe familial hemiplegic migraine syndrome in humans. Front Cell Neurosci 9:8. CrossRef Medline

Vinet J, Sík A (2006) Expression pattern of voltage-dependent calcium channel subunits in hippocampal inhibitory neurons in mice. Neuroscience 143:189-212. CrossRef Medline

Westenbroek RE, Sakurai T, Elliott EM, Hell JW, Starr TV, Snutch TP, Catterall WA (1995) Immunochemical identification and subcellular distribution of the alpha 1A subunits of brain calcium channels. J Neurosci 15:6403-6418. CrossRef Medline

Xu J, Wu LG (2005) The decrease in the presynaptic calcium current is a major cause of short-term depression at a calyx-type synapse. Neuron 46:633-645. CrossRef Medline

Yan J, Leal K, Magupalli VG, Nanou E, Martinez GQ, Scheuer T, Catterall WA (2014) Modulation of $\mathrm{Ca}_{\mathrm{V}} 2.1$ channels by neuronal calcium sensor- 1 induces short-term synaptic facilitation. Mol Cell Neurosci 63:124-131. CrossRef Medline

Zamponi GW, Striessnig J, Koschak A, Dolphin AC (2015) The physiology, pathology, and pharmacology of voltage-gated calcium channels and their future therapeutic potential. Pharmacol Rev 67:821-870. CrossRef Medline

Zucker RS, Regehr WG (2002) Short-term synaptic plasticity. Annu Rev Physiol 64:355-405. CrossRef Medline 